сийского государственного педагогического университета им. А. И. Герцена, 2008. № 69. С. 527-531.

8. Хуан Пин. Китайское фортепианное искусство первой половины XX века в его взаимосвязях с русской фортепианной школой. URL: http://www.opentextnn.ru/music/interpretation/index.html@id=5874

9. Шнеерсон Г. М. Музыкальная культура Китая. Москва, 1952. 320 с.

10. Ю Жунь Ян. Правила инструментального творчества. Народная музыка, 1979.

11. Янь Чжихао. Проблеми фортепіанного мистецтва Китаю у працях китайських дослідників. Українська музика. 2017/4 (26). С. 94-101.

\title{
References
}

1. Abdullin G.V., Sun Ya. (2018). Features of Chinese piano music of the second half of the twentieth century. Manuscript. Tambov: Certificate,11 (97). Part 2, 322-326 [in Russian].

2. Gaidai, P.V. (2014). The role of traditional music culture in the development of piano art in China. News of the Volgograd State Pedagogical University, 3 (88), 61-64 [in Russian].

3. Hakkel L. (1976). Piano music of the twentieth century. Essays. Leningrad-Moscow: Soviet Composer [in

4. Ivlev, L. Ten paragraphs about the "literature of scars". URL: sanwen.ru/2012/01/04/desyat-abzacev-oliterature-shramov [in Russian].

5. Li Yun. Piano Arrangement in the History of Chinese Music.URL: http://publishing-vak.ru/file/archive-culture2017-5/33-li-yun.pdf [in Russian].

6. Mao De Dong. Talking to a musician. Party Guide to the 1956 Art. [in Russian].

7. Juan Ping (2008). Boris Zakharov and his role in the formation of a Chinese piano school. News of the Russian State Pedagogical University. Al Herzen, 69, 527-531 [in Russian].

8. Juan Ping. Chinese piano art of the first half of the twentieth century in its relationship with the Russian piano school. URL: http://www.opentextnn.ru/music/interpretation/index.html@id=5874 [in Russian].

9. Schneerson G.M. (1952). Music culture of China. Moscow [in Russian].

10. Yu Jun Yang (1979). Rules of instrumental creativity. Folk music [in Russian].

11. Yan Zhihao (2017). Problems of Piano Art of China in the Works of Chinese Researchers. Ukrainian music, 4 (26), 94-101 [in Russian].

Стаття надійшла до редакції 06.11.2019 р. Прийнято до публікації 29.11.2019 p.

УДК 75.046.3:27-526.62]:[1+2]

\author{
Дем'янчук Андрій Львович \\ кандидат мистецтвознавства, \\ доцент кафедри режисури та хореографії \\ Львівського національного університету \\ імені Івана Франка \\ ORCID 0000-0002-3399-4537
}

\section{ФІЛОСОФСЬКІ ТА БОГОСЛОВСЬКІ ОСНОВИ ІКОНОТВОРЧОСТІ}

Мета статті - дослідити фрілософські та богословські основи іконотворчості, з'ясувати матеріальну та духовну природу ікони, встановити її основну відмінність від несакрального світського мистецтва. Показати роль канонічної ікони у християнському храмі, розкрити її зв'язок з Літургією. Методологія. У дослідженні застосовано комплекс методів, а саме: історичний, порівняльний, метод аналізу та узагальнень, описовий, іконографічний (принципи та методи зображення); технологічний; богословський (аналіз текстів Біблії); фрілософрський (сутність і явище; зміст і форма; необхідність і випадковість та ін.); індуктивний та дедуктивний методи тощо. Завдяки цим методам було досліджено богословські та фрілософські основи іконотворчості, з'ясовано духовну та матеріальну природу ікони та її відмінність від світського мистецтва. Наукова новизна роботи визначається розкриттям філософських та богословських основ іконотворчості. У цьому контексті було встановлено матеріальну та духовну природу ікони, зокрема, розкрито ії глибинний зв'язок з Літургією. Висновки. Ікона - сакральний твір, який має не тільки матеріальну але й духовну природу. Це пояснює її тісний зв'язок з Літургією. У ній також закладені фрілософські та богословські основи, які не суперечать, а доповнюють усталені канонічні іконографічні правила вироблені в IX-X ст., а також національні мистецькі традиції. Нині у сакральному мистецтві поряд з використанням усталеної традиційної символіки, існують і намагання створити нові зразки трансцендентальної ікони. Пригадаємо, що основою трансцендентальної ікони є Божі тайни, які доступні пізнанню як апріорному, так і апостеріорному. Тож ікона через свою трансцендентальну природу повинна, як це робить слово Боже у Біблії, виявляти Божі таємниці і доносити їх до всіх людей. Ікона $€$ також метафрізична. $€$ багато означень цього терміну в фрілософрії, але в богослов"ї метафізика має конкретний зміст: це високий духовний світ Божого буття. У цьому світі перебуває Воскреслий Господь і його святі. А вони є об'єктами зображень на іконах. Ікона є онтологічна, оскільки вона виразно вказує на можливість пізнання розумом першопричин буття. Проте вивчення проблеми філософських та богословських основ іконотворчості, ще потребують глибших досліджень та нових наукових підходів. нування.

Ключові слова: богословські та фрілософські основи іконотворчості, френомен ікони, основи іконоша-

(С) Дем'янчук А. Л., 2020 
Демьянчук Андрей Львович, кандидат искусствоведения, доцент кафедры режиссуры и хореографии Львовского национального университета им. Ивана Франко.

\section{Философские и богословские основы иконотворчества}

Цель статьи - исследовать философские и богословские основы иконотворчества, выяснить материальную и духовную природу иконы, установить ее основное отличие от несакрального светского искусства. Показать роль канонической иконы в христианском храме, раскрыть ее связь с Литургией. Методология. В исследовании применен комплекс методов, а именно: исторический, сравнительный, метод анализа и обобщений, описательный, иконографический (принципы и методы изображения); технологический; богословский (анализ текстов Библии) философский (сущность и явление, содержание и форма, необходимость и случайность и др.) индуктивный и дедуктивный методы и тому подобное. Благодаря этим методам были исследованы богословские и философские основы иконотворчества, выяснено духовную и материальную природу иконы и ее отличие от светского искусства. Научная новизна работы определяется раскрытием философских и богословских основ иконотворчества. В этом контексте было установлено материальную и духовную природу иконы, в частности, раскрыто ее глубинную связь с Литургией. Выводы. Икона - сакральное произведение, имеет не только материальную но и духовную природу. Это объясняет ее тесную связь с Литургией. В ней также заложены фрилософрские и богословские основания которые не противоречат, а дополняют устоявшиеся канонические иконографические правила выработанные в IX-X вв., а также национальные художественные традиции. Сейчас в сакральном искусстве наряду с использованием сложившейся традиционной символики, существуют и попытки создать новые образцы трансцендентальной иконы. Вспомним, что основой трансцендентальной иконы есть Божьи тайны, которые доступны познанию как в априорном, так и в апостериорном. Поэтому икона из-за своей трансцендентальной природы должна, как это делает слово Божие в Библии, проявлять Божьи тайны и доносить их до всех людей. Икона также метафизическая. Есть много определений этого термина в философии, но в богословии метафизика имеет конкретный смысл: это высокий духовный мир Божьего бытия. В этом мире находится Воскресший Господь и его святые. Они являются объектами изображений на иконах. Икона является онтологической, поскольку она определенно указывает на возможность познания умом первопричин бытия. Однако изучение проблемы философских и богословских основ иконотворчества, еще нуждаются в более глубоких исследованиях и новых научных подходах.

Ключевые слова: богословские и философские основы иконотворчества, феномен иконы, основы иконопочитания.

Demianchuk Andrii, Ph.D. in Arts, associate professor of the Department of Stage Production and Choreography of the Lviv Ivan Franko National University.

Philosophical and theological principles of icon-painting

The purpose of the article is to study philosophical and theological principles of icon-painting, explain the material and spiritual nature of the icon, determine its principal difference from the non-sacral secular art, to show the role of the canonical icon in a Christian temple, its link with Liturgy. Methodology. A complex of methods has been applied in the study, such as: historical, comparative, analysis and generalization methods, descriptive, iconographic (principles and methods of depiction); technological; theological (analysis of the Bible texts); philosophical (substance and phenomenon; content and form; necessity and chance, etc.); inductive and deductive methods, etc. Owing to these methods we have studied philosophical and theological principles of icon-painting, explained the spiritual and material nature of the icon and its difference from secular art. The scientific novelty of this work is in revealing the role of philosophical and theological principles of icon-painting. In this context, we have studied the material and spiritual nature of the icon and, in particular, revealed its fundamental link with Liturgy. Conclusions. The icon is a sacral work that has not only the material but spiritual character as well. This explains its link with Liturgy. It is based on the philosophical and theological principles that do not contradict but supplement the established canonical iconographic rules elaborated in the $9-10^{\text {th }}$ centuries and the national art traditions. In today's sacral art along with the use of the established traditional symbols there exist attempts to create the new specimens of a transcendental icon. We shall note that the underlying rationale of the transcendental icon is God's secrets open to perception a priori (through faith) and a posteriori (through experience). Therefore, the icon through its transcendental nature must, as it is done by the Word of God, reveal God's secrets and deliver them to all people. The icon is also metaphysical. This is a very valuable property that makes it different from other works of secular art, for example, from a portrait. There are many definitions of this term in philosophy, but metaphysics in theology has a concrete content: this is a high spiritual world of God's existence. Jesus resurrected from the dead and His saints are in this world and they are the objects of imaging in the icons. The icon is ontological as it expressly shows the possibility of a perception of the supreme cause of existence. In the philosophy ontology is the branch exploring the supreme foundations of all things in existence, sources of existence, moving forces of the world-building. Christian ontology shows God as the primary source of all things in existence. However, exploring the problem of philosophical and theological principles of icon-painting still requires more detailed studies and new approaches.

Key words: theological and philosophical principles of icon-painting, a phenomenon of the icon, principles of icon veneration.

Актуальність теми дослідження зумовлена важливістю дослідження і розкриття фрілософськобогословських основ іконотворчості, які і досі залишаються недостатньо дослідженими. Тема дослідження актуалізується і тим, що френомен ікони викликає значний інтерес у багатьох науковців, зокрема, фрілософрів, релігієзнавців, богословів, істориків а також мистецтвознавців та майстрів сакрального мистецтва.

Аналіз досліджень і публікацій. Досліджуючи основи іконотворчості було опрацьовано наукові праці з історії і теорії мистецтва, філософії та богослов'я вітчизняних і зарубіжних учених [1-4; 9-25; 27-35]. Про іконологію, іконографрію та стилістику давніх і новітніх ікон, зокрема українських, дізнаємося 3 наукових праць Д. Степовика [18-21]. Історичні мистецтвознавчі, а також фрілософсько- 
богословські основи ікони висвітлюються у монографіях вченого «Іконологія й іконографрія» [19], «Мистецтво ікони: Рим, Візантія, Україна» [21]. У цих працях проаналізовані великі труднощі, з якими зіткнулася Вселенська Церква, утверджуючи сакральні зображення, як візуальної віронавчальної частини богословії. Історичні літургійні та богословські аспекти висвітлені у працях А. Карташева «Вселенскі собори» [8], Я. Креховецького «Богослов'я та духовність ікони» [13], І. Музичка «Українське священне мистецтво і богословія» [15], Ю. Катрія «Пізнай свій обряд» [9] та ін.

Давню візантійську іконографрію, зокрема, її вплив на мистецтво Київської Русі-України, досліджували зарубіжні вчені, зокрема, російські: Н. Кондаков «Іконографрія Богоматері» [11; 12] та інші його праці; В. Лазарєв «Етюди з іконографрії Богоматері» [14], В. Бичков «Візантійська естетика. Теоретичні проблеми» [1], а також праці інших вчених.

У цих наукових працях окрім розкриття основних фрілософрсько-богословських аспектів іконотворчості, виявлено й малодосліджені ділянки які стосуються феномену ікони. Зокрема, малодослідженою є проблема розкриття тих аспектів, які стосуються матеріальної та духовної природи ікони, ії глибинного зв'язку з Літургією.

Мета статті - дослідити богословські та фрілософрські основи іконотворчості, з'ясувати матеріальну та духовну природу ікони, встановити її основну відмінність від несакрального світського мистецтва. Показати роль освяченої канонічної ікони у християнському храмі, розкрити ії глибинний зв'язок зі Святою Літургією.

Виклад основного матеріалу. Ікона не тільки мистецький твір який передає стиль епохи, а духовний орієнтир, трансцендентальне світло, яке допомагає людині спілкуватися з Богом. Тому при створенні канонічної трансцендентальної ікони [26, 647] використовується традиційна символіка, яка в усі часи була панівним засобом у сакральному мистецтві. Зауважимо, що латинське слово transcendere означає переступати. Від цього слова походять два фрілософських поняття: трансцендентне, тобто таке, що не може бути пізнане, оскільки лежить за межами людського пізнання; і трансцендентальне, яке визнає значущість пізнання того, що лежить поза межами сприйняття нашими органами почуттів. Надмірний символізм ікони, утворений за допомогою умовностей і деформацій, на думку деяких філософрів, виявляє в іконі трансцендентність, тобто непізнанність зображеного Божого світу, розмежованість споглядання і людського досвіду. Такий спосіб творення і сприйняття ікони пропонує російський фрілософ П. Флоренський $[27 ; 28,249]$. Натомість український мистецтвознавець Д. Степовик у своїх працях визначає фрілософську основу ікони як трансцендентальну [19-21]. Ці визначення основані на тому, що в іконі $є$ Божі тайни, які доступні пізнанню як апріорному (тобто здобутому через віру), так і апостеріорному (тобто здобутому на основі досвіду). Бог нічого не приховав від людини, а розкрив їй ту частину таємниць, які стосуються ії̈ особистого спасіння та людства в цілому. Тож ікона через свою трансцендентальну природу повинна, як це робить слово Боже у Біблії, виявляти Божі таємниці і доносити їх до всіх християн.

Трансцендентальність ікони передбачає високий рівень єдності споглядання, думання і досвіду. Зазначимо, що просте поверхневе споглядання веде до пасивності, відчуження і байдужості, а думання й набуття досвіду - до раціоналізму. У єдності вони творять активний, дійовий характер відносин Бога і людини (Творця і твору). Таким чином, пізнання того, що лежить за межами сприйняття і досвіду, є спробою людини увійти в природу Божих таємниць. А найбільшою таємницею є Втілення, коли Всемогутній Бог своєю святою і суверенною волею став людиною в особі Ісуса Христа (другій Особі Пресвятої Тройці) і дав себе пізнати. Більше того: коли його найближчі учні, апостоли, не розуміли значення біблійних текстів, він активізував їхнє пізнання, розповідаючи їм притчі. Так Господь сам давав приклади трансцендентальної логіки, вводячи апріорні знання в апостеріорне буття людини. Після Христа цю саму роботу виконує Церква, а також ікона, що є важливим інструментом для пізнання Бога і його об'явленнь.

3 огляду на це ікона також метафрізична [26, 372]. Це дуже цінна і важлива їі риса, яка відрізняє ії̈ від інших творів малярства, наприклад від портрета. Метафізика означає поняття, що існує поза природою, поза фізикою. $€$ багато означень цього терміну в філософії, але в богослов"ї метафрізика має конкретний зміст: це високий духовний світ Божого буття. У цьому світі перебуває Воскреслий Господь і його святі, які $€$ об'єктами зображень на іконах. Інакше кажучи, метафізичний образ у християнстві - це високодуховний образ. Питання полягає в тому, як маляреві домогтися цієї надприродності за допомогою цілком природних речей - образів видимого світу і матеріалів для малювання. Середньовічний маляр ікон вирішував це питання за допомогою деформацій видимого простору. Детально описав і проаналізував просторові деформації давніх майстрів малярства, і зокрема російського, вчений Б. Раушенбах [17]. Описані ним методи просторових побудов у релігійному малярстві ілюструють прагнення мистців досягти метафізики ікони за допомогою певної деформації. Звичайно, це є один з виявів символіки. Проте на початку формування богослов'я ікони, створено Богом красу й досконалість природи розуміли як відблиск того раю, в якому жили Адам і Єва до гріхопадіння. Тож вищий духовний світ варто передавати не як погіршений варіант видимого світу, а, навпаки, як незрівнянно кращий від нього.

Метафізика в іконах виступає як джерело всього сущого, як вічна, незмінна і довершена даність. Метафрізичне в іконах - це справді духовне, підняте над природою єство, де форма, колір, 
лінія, площина, простір природно досконалі.

3 метафізикою божественного світла в іконному малярстві нерозривно пов'язані світло і колір. Діонісій Ареопагіт (Новий) переніс свої роздуми про світло на кольори, зробивши світло і колір нерозривними поняттями. Про це, зокрема, довідуємося з його праці «Корпус Ареопагітикум». Цю теорію доповнив своїми славними проповідями Іван Дамаскин (перша пол. VIII ст.) [31].

3 метафізикою тісно поєднується наступна філософська категорія -ідеальність. У богословському й іконологічному розумінні ідеальне зовсім не $є$ похідним від матеріального. Відмінність духовної ідеальності від земної, матеріяльної чітко окреслив апостол Павло у таких словах: «чого око не бачило й вухо не чуло, і що на серце людині не впало, те Бог приготував був тим, хто любить його!» (Перше послання св. апостола Павла до коринтян, 2:9). тут не описується, не конкретизується, що саме приготовлено Богом для його святих, але явним $є$ те, що цьому приготовленому Богом нема аналогій у матеріальному світі. Це нагадує і Новий Єрусалим (тобто змінений Богом світ), про який ідеться у 21му розділі Об'явлення Івана Богослова. Ідеальне виражається в іконі насамперед через золотий німб навколо голови святої людини і через золоте тло. Це образ ідеального простору, свого роду проекція небесного на земне.

Іконотворчість базується на усталених канонічних правилах, які $€$ частиною богослов'я ікони, тому в християнському храмі вона тісно пов'язана з Літургією. Пригадаємо, що конкретні сюжети ікон і основні правила їх зображення були закріплені у актах Сьомого Вселенського (Другого Нікейського) собору 787 р. [8; 35]. Причини пошанування ікон подані в Єрмінії: «Малювання святих ікон запозичили ми не тільки від святих отців, а й від святих апостолів і навіть від самого Христа, як-то показали ми на початку цієї книги. Тому ми зображуємо Христа на іконі як людину, бо він з'явився на землі і жив 3 людьми, ставши досконалою людиною, як і ми, крім гріха...» [5, 941-942].

Про неухильність дотримання канонів у священному мистецтві ми насамперед згадуємо, коли говоримо про християнство східного, візантійського обряду. Колись ця конечність канонів була притаманна обом обрядовим системам у християнстві - латинській і візантійській. Проте після розділення Церкви (1054) обрядові розходження між Католицькою і Православною Церквою торкнулися і концепції священного мистецтва. В епоху Передвідродження і Відродження (Проторенесансу й Ренесансу) у сакральному мистецтві Римської Католицької Церкви почали формуватися нові правила. Поряд з традиційним візантійським іконним малярством, яке дало нові плоди на італійському грунті (Чімабуе, Джотто, Дуччо), розвивається й високо-духовний релігійний живопис (Корреджо, Белліні, Тіціан). У мистецтві грецької та інших православних церков продовжували дотримуватися постанов Сьомого Вселенського собору 787 р. із урахуванням уроків трагічної 117-річної доби іконоборства (726-843) і вироблених у IX-X ст. канонів іконографії.

Унікальність України полягає в тому, що вона упродовж століть намагалася не тільки примирити дві гілки християнства, але й синтезувати східну і західну концепції священного мистецтва. Ось основна фундаментальна причина, чому саме в Україні в ікону було введено стильові риси західного походження, зокрема ренесансу і бароко. «Двадцяте століття, - пише відомий український богослов отець Іван Музичка, - непомітно внесло під впливом довгожданого контакту східних Церков із західними богословське зацікавлення священним мистецтвом. На наших очах священне мистецтво увійшло в богословію вже майже як locus theologicus. (...) у східних Церквах священне мистецтво було дуже тісно пов'язане з Літургією, було його невід'ємною, органічною частиною, брало в ній духовну чинну участь...» $[15,146]$. Хоч це сказано про східне священне мистецтво взагалі, але думка богослова повністю відповідає сучасній іконі.

Пригадаємо, що візантійський іконографічний канон був сформований у вченні богословів і у творчості мистців після жахливої драми іконоборства, яка потрясла Візантію у VIII-IX ст. та примусила константинопольських богословів приділити чільну увагу саме іконі, її ролі в християнському храмі, а також методові її творення мистцями.

Після перемоги над іконоборством і установленні в честь цієї події свята (843), візантійці започаткували глибоку реформу всього сакрального мистецтва, щоб втілити в життя постанови Сьомого Вселенського собору щодо ікон (787) та ідеї найвидатніших богословів-іконологів Візантії раннього Середньовіччя - Івана Дамаскина і Теодора Студита [31; 34]. Преподобні отці Сьомого Вселенського собору, як і святі Іван і Теодор, обґрунтували саму ідею пошанування ікон, її глибинний онтологічний зв'язок з фундаментальними догматами християнства, але не вдавалися в деталі, як треба творити ікони. Тобто вони виступили скоріше як іконологи, ніж як іконографи.

Ікона є онтологічна, оскільки вона виразно вказує на можливість пізнання розумом першопричин буття. У філософії онтологія є галуззю, яка досліджує вищі основи всього сущого, джерела існування, рушійні сили світобудови $[26,449]$. Проте християнська онтологія вказує на Бога як на першоджерело всього сущого. Початок книги Буття, першої книги Біблії, має класичний онтологічний характер. Також у святому Письмі Старого й Нового Заповітів можна знайти чимало місць, які вказують на Бога як на творця людини. Спонука надчуттєвих резервів людини, політ думки до найвищих форм буття духу роблять онтологію ікони необхідною і визначальною рисою - пізнання через неї природи Бога. Тому онтологічні основи Біблії органічно увійшли в іконотворчість. Однією з основних рис ікони $€$ іï антропологізм [26, 26]. У християнстві фрілософрська категорія антропологізму, подає най- 
послідовнішу, найгуманнішу концепцію людини. Вона має свої відмінності як від античного (Сократівського), так і від класичного (Фейєрбахівського) антропологізму. Зазначимо, що людиноцентризм притаманний багатьом філософським школам, але тільки у християнській антропології він знаходить повноту і завершеність. Сократ поставив людину в центр пізнання. Класична просвітницька фрілософрія розглядала людину як вершину на піраміді природи. Християнська ж антропологія твердить, що основою всесвіту $є$ Бог, а людина є довершеним творінням Бога. Таким довершеним, що на певному етапі Бог сам став людиною.

Іконотворчість, що твердо стоїть на позиції креаціонізму (вчення про Божественне створення світу), у мистецькій формі передає саму суть християнської антропології [26, 307]. Якщо в деяких нехристиянських релігіях існує категорична заборона зображати у храмах людину (наприклад, в юдейських синагогах, магометанських мечетях), то в інтер'єрах католицьких і православних християнських храмів є багато зображень людини. Це не об'єкти поклоніння, а християнські співмолільники до єдиного Всемогутнього Бога.

Більше того, в іконостасах Церков східного обряду торжествує ідея боговтілення: втілений Господь перебуває поряд зі своїми святими. Він і вони є небожителями, що населяють царство небесне. Так людське підноситься до божественного, а божественне, у свою чергу, не ігнорує, а освячує людське. Ось чому антропологізм ікони не тотожний обожненню людини, він не має нічого спільного ні з пантеїзмом східних релігій, ні з політеїзмом інших релігій. Ікони християнського храму яскраво і виразно проводять євангельську ідею: центром і першопричиною всесвіту є Бог (тому христологічні ікони містяться у центрі іконостаса), а центром Божої творчості є людина. Решта елементів сакрального мистецтва у храмі (різьба на іконостасах, орнаменти, вишивки тощо) увиразнюють і підкреслюють цю глибинну взаємодоповнюваність теоцентризму і антропологізму. І чим довершеними з мистецького боку є орнаментальні частини ікономалярства, увесь декоративний супровід ікон, тим більшу силу впливу має ікона на віруючих.

3 преамбули до канонів Сьомого Вселенського Собору довідуємося: «...на святих чашах, на одязі, у приватних будинках мусять залишатися ікони нашого Спасителя і Бога Ісуса Христа, Пречистої Діви Марії Богородиці, ангелів, усіх святих і побожних людей. Чим більше їх буде для споглядання людьми, тим більше душі людей підноситимуться до них. Їм, іконам, треба віддавати від душі відповідну повагу, а не уклін матеріалові, з якого їх зроблено» [22, 259].

Трульський помісний собор візантійської Церкви прийняв постанову (82-й канон), якою поклав край поширеним доти зображенням Спасителя у вигляді символічних знаків і алегоричних постатей (агнець, орфей, пелікан, добрий пастир, риба, виноградна лоза, голуб, фенікс, дельфін та ін.). Собор встановив для змалювання на іконах історичний образ Ісуса Христа як Людини, яка повністю зберегла свою природу Бога, але одночасно набула і другу природу - тілесної людини. Трульський собор встановив, що з народженням Ісуса Христа людство познайомилося з Богом особисто, бачило Його впродовж 33 років. Він сам залишив два своїх автентичних зображення на тканинах (на рушнику едеського царя Авгара V і на рушнику блаженної Вероніки), а Його Матір, Богородицю Марію, змалював євангеліст Лука ${ }^{1}$ Отже, надзвичайно важливий догмат християнства про боговтілення Трульський собор офріційно вводив у практику іконошанування й ікономалярства: замість символів та алегорій, Господь мав бути зображений на іконах в людському образі [105, 249].

Майстри-малярі столичної константинопольської школи на основі іконології отців Церкви розробили практичні правила малювання, тобто практичну іконографію, і уклали їх у вигляді своєрідних рукописних підручників, які по-грецькому називалися єрмініями. Розсилаючи їх по візантійській державі та за її межі, де плекалося мистецтво ікони, столичні майстри упродовж наступних (після дев'ятого) століть створили безпрецедентну популярність візантійської ікони на Близькому Сході, в Закавказзі, на Балканах, в Русі-Україні, в Італії, Сицилії, Африці, на островах Середземного моря. Багато цих єрміній зникло, а ті, що збереглися з давніх віків у монастирях Афонського півострова, грецький чернець Діонисій з Фурни зібрав разом і у XVIII ст. опублікував [5]. Таким чином було вироблено канони ікони, які включали в себе три положення: іконографію (коло святих, допущених до зображення на іконах), стилістику (мистецькі засоби малювання святих), техніку (матеріали, які слід використовувати для малювання святих). Ці канони передавалися до країн, які приймали християнство візантійського обряду.

Ікони, на яких присутня свята постать Спасителя, канон чітко поділяє на дві групи: ті, які відображають земне життя Господа, і ті, які представляють Його як Царя Небесного або Суддю. Перша група - це згадані шість господніх ікон святочного ярусу іконостаса. Щодо другої групи, то візантійський канон установив такі образи господа: Вседержитель, або грецькою Пантократор; Христос-Цар; Христос Великий Архієрей «ти священик навіки за чином мелхиседековим» (Псалом 110:4); Пресвята Трійця. Східна Церква плекає дві ікони про Трійцю: як троє ангелів, що з'явилися з місією до Авраама й Сарри (Старозаповітна Трійця), і як Бог- Отець, Бог-Син і Бог-Дух Святий (Новозаповітна Трійця); Христос - Суддя світу (ця ікона була надзвичайно популярна у західній Церкві в епоху Середньовіччя. Прикладом можуть слугувати зображення на тимпанах романських та готичних храмів).

Дослідник візантійської іконографії, Н. Кондаков виділяє у візантійському мистецтві сім іконографічних варіантів Ісуса Христа, покликаних стверджувати найважливіші догматичні постулати хри- 
стології: 1. Спас Нерукотворний, 2. Спас Ветхий Днями, або Саваот, Спас Немовля, або Еммануїл, 4. Спас Великий Архієрей, 5. Спас - Ангел Великої Ради, 6. Спас Вседержитель, 7. Спас Милостивий, або Сотер [10]. Українська ікономалярська традиція успадкувала більшість із цих варіантів. Тут доцільно згадати ікону Спаса Нерукотворного, яка стоїть на першому місці в усій християнській іконографії, бо, за церковною оповіддю, Ісус Христос за свого земного життя принаймні двічі залишив власний образ на двох різних тканинах: на рушнику едеського царя Абгара $\mathrm{V}$ i на рушнику святої Вероніки. Обидва образи подібні до лику Господа на Туринській плащаниці, тому є певні підстави вважати рушники Абгара й Вероніки автентичними зображеннями Спасителя у момент завершення ним своєї земної місії [25, 412-413]. Церква прийняла ці два образи, оповиті легендами, за взірцеві при змалюванні Спасителя. Звичайно, оригінали рушників Авгара і Вероніки не збереглися, але 3 їх допомогою було сформовано церковну традицію, котру рівною мірою використали як богослови у догматі боговтілення, так і мистці при утвердженні культу Ісуса Христа в ікономалярстві.

Богородична тематика на іконах сучасних малярів також відповідає богословським вимогам. Візантійська іконологія розробила сім основних варіантів ікон Богородиці, окрім шести ікон зі святочного яруса: 1. Заступниця, або грецькою Оранта, 2. Знамення, або Панагія чи Влахернітіса, 3. Дейзисна (Молільна), або Агіосорітіса, 4. Переможниця, або Нікопея, 5. Провідниця, або Одигітрія, 6. Ніжності, або Єлеуса, 7. Вознесіння Богородиці, або Асунта [11; 12]. Однак у візантійській іконографії відомі й менш поширені образи святої Діви, наприклад, коли вона грається з маленьким Ісусом, тримаючи його на руках (Гра, або так зване Взиграніє), і коли вона годує його своєю груддю (Годувальниця, або Галактотрофуса) [14, 275-329].

На прикладі іконографії цих ікон можемо спостерігати цікаве явище, а саме поєднання еклезіології (вчення про Церкву) в один вузол з християнською антропологією (вченням про людину). Виділення особливого молитовного стану й особливої ласки та лагідності в намісних Богородичних іконах є дуже важливим богословським акцентом у сучасній іконотворчості. Молитва - це те, чого хоче від людини Бог. Любов - це те, чого хоче людина від Бога і від ближнього. Але ці взаємини вирішуються в іконі не словесно (як, наприклад, у богословських трактатах), а зображально: Діва Марія представляє людський рід, Ісус Христос - Святу Трійцю. Звичайно, тут діє велика сила узагальнення, яке може дати тільки мистецтво з його розвиненими методами метафор та асоціацій.

Як і давні майстри, наші сучасники прийняли й певні візантійські деформації та умовності [1, 154-165; 2, 257-268]. В даному контексті слід зауважити, що йдеться про узвичаєні мистцями, вироблені тривалою мистецькою творчістю іконографрічні методи.

У богословському каноні, який сформувався на рішеннях святих соборів щодо ікон (Трульського Помісного, Сьомого Вселенського), праці Східних і Західних Отців на теми церковної образотворчості (Діонисія Ареопагіта Нового, Івана Дамаскина, Теодора Студита, святих Єронима й Августина та ін.), ніде не знайдемо обґрунтування на євангельській чи святоотцівській основі необхідності у деформаціях, площинних зображеннях чи оберненій перспективі.

Подібним рекомендаціям слідували всі візантійські майстри сакрального мистецтва. Прикладом може слугувати велика виставка візантійського мистецтва у США (Метрополітен музей, Нью-Йорк, 1997) доби між 843 і 1261 роками, де було представлено експонати з двадцяти чотирьох країн світу, дуже мало творів візантійського мистецтва містять у собі вищезазначені стильові засоби ${ }^{2}$ [33].

Таким чином, можна констатувати, що площинність, деформації, обернена перспектива та інші засоби не були характерними для візантійських ікон тієї доби, коли сакральне мистецтво у Візантії було піддане глибокій реформі після сумновідомої доби іконоборства (726-843). Реформа ж відбулася у другій поло- вині IX і в X столітті, тож не дивно, що Русь-Україна, яка прийняла християнство (i, звичайно, всю мистецьку інфраструктуру храму) від Візантії наприкінці цього періоду, не успадкувала жодних обернених перспектив і деформацій в іконі. Принаймні збережені до нашого часу київські ікони до монгольської доби не мають вищезазначених рис [23, табл. 1-15]. Проте такі риси починають подекуди з'являтися у візантійських іконах в останній період існування візантійської імперії, при правлінні представниками династії Палеологів [16, 435-518; 18, 223-238; 32].

Спроби пов'язати богослов'я з низкою формальних засобів в ікономалярстві здійснили у XX ст. російські іконологи. Поштовх для цього було дано ще перед Першою світовою війною в російському православному середовищі в академічному світі якого поступово склалася своєрідна символічна школа іконологів, яка тонко переплела богослов'я, теорію й історію ікономалярства. До неї належать П. Флоренський, Б. Раушенбах, С. Булгаков, С. Спаський, С. Аверінцев, Л. Успенський, І. Язикова, а також певною мірою М. Алпатов, В. Лазарев, В. Брюсова, В. Бичков. Наприкінці XX і на початку XXI ст. в Москві та Санкт-Петербурзі з'явилися нові імена молодших мистців, мистецтвознавців і фрілософрів, які продовжують пошуки у вивченні символізації ікон з Біблією і богословською літературою. В сучасній іконотворчості приділяється велика увага до ікони, як унікальної галузі сакрального мистецтва, здійснюється спроба трактувати ікони і навіть цілий іконостас у контексті символів [17]. Зокрема, наділяти матеріали, які використовуються при малюванні ікон, надзвичайними властивостями [24; 29]. Певною мірою іконі притаманний містицизм (від грецьк. нибтп́рıоv - таємниця, таїнство) [26, 386]. Це найбільш контроверсійна риса ікони, бо містичне (з грецької - таємниче) властиве і багатьом нехристиянським релігіям та їх мистецтву ${ }^{3}$. Але містицизм у християнстві обмежений лише святими тайна- 
ми, установленими Господом. Кожна ікона розкриває певну Божу тайну або їх сукупність. Сама Божественна Літургія є таїнством, бо її вершиною є Свята Євхаристія - причастя тіла і крові Ісуса Христа, тобто не тільки духовне, але й фрізичне єднання зі Спасителем.

Перебуваючи в церкві, християнин усвідомлює онтологічну мету цих дій, але механізм їх упровадження (скажімо, тайну зачаття і народження Христа) він може осягнути тільки на містичному рівні. Сама віра християнина в те, чого не можна довести за законами логіки, також є містичним актом.

Містичними ознаками наділені чудотворні ікони, так як через їх посередництво здійснюється незбагненний вплив життєдайної сили Духа Святого при зціленні, врятуванні від небезпеки й інших чудах. У церкві існує незліченна кількість історичних фрактів, які це підтверджують. Проте усі спроби розпізнати, пояснити, як це відбувається, не мають успіху, так як це є частиною творчої Божої енергії, закони якої відомі тільки самому Богові. 3 огляду на це ікона наділена ознаками милосердя, бо зображає Милосердного Господа, котрий творив милосердя 4.

Підсумовуючи, зазначимо, що філософсько-богословські основи іконотворчості виходять далеко за межі ілюстративності стосовно Біблії й історії Церкви. Ікона увібрала в себе віру і мудрість, вироблені християнською спільнотою за дві тисячі років християнської цивілізації. У цьому полягає унікальність та універсальність ікони у християнській концепції пізнання та пошанування Бога. Хоча ікона і зародилася на християнському сході (згідно церковного передання перші ікони створив євангеліст Лука наприкінці I ст. по Різдві Христовім), вона мала великий вплив і на західне малярство. Це, зокрема, видно при дослідженні творчості таких італійських майстрів Проторенесансу, як Джотто ді Бондоне та Дуччо ді Буонінсенья. Ідеальність в іконі включає в себе все, що пов'язується з вічним і сталим, а не 3 тимчасовим і мінливим. Господь, усі святі $є$ вічно сущими, незмінними, тому на іконах малюють їхній ідеал. Вічність Божого буття - це пульсація конечного і безконечного: конкретні форми Божого творіння змінюються і переходять у просторі й часі, а вічний Божий ідеал ніколи не змінюється, немов пронизуючи собою ці мінливі конкретні фрорми. Ідеальне в іконі відображає першопричину творення незбагненний світ Творця.

Важливою ознакою іконотворчості $€$ дотримання усталених канонів сакрального мистецтва (теорії і практики іконного малювання), вироблених теоретиками - іконологами та іконографами періоду іконоборства базованих на Святому Письмі та Літургії.

\section{Примітки}

1 Третім автентичним зображенням Господа Ісуса Христа вважають плащаницю з Туринського кафедрального собору св. Івана Хрестителя в Італії.

2004 p. ${ }^{3}$ Інша міжнародна виставка візантійського мистецтва доби династії Палеологів у цьому ж музеї відбулася буддизм, індуїзм, окультизм, синтоїзм, спіритизм, теософія та інші релігії, секти і культи.

4 За посередництвом ікон люди отримували зцілення з невиліковних недуг упродовж багатьох віків. Нині відомо про десятки тисяч науково підтверджених та документально зафіксованих чудесних зцілень.

\section{תimepamypa}

1. Бычков В. Византийская эстетика. Теоретические проблемы. Москва: Искусство, 1977. 237 с.

2. Бычков В. Малая история византийской эстетики. Киев: Путь к истине, 1991. 408 с.

3. Бычков В. Эстетика Аврелия Августина. Москва: Искусство, 1984. 264 с.

4. Галуйко Р. Софріологічний аспект догмату іконошанування у концепції Сергія Булгакова. Вісник Львівського університету. Серія фрілософські науки. 2012. Вип. 15. С. 227-234.

5. Дионисий Фурноаграфиот. Ерминия, или Наставление в живописном искусстве. [Составленное в 1701-1755 годах]. Труды Киевской Духовной Академии. Київ: Типография Киевской Духовной Академии, 1868. № 2. 161 с. (перевидання: Москва, 1993).

6. Дубінський Б. Туринська плащаниця - свідчення віри і наукова таємниця сучасності. Мета. Львів, квітень 2000. 44 (137).

7. конографія Свято-Миколаївської церкви. Торонто: вид-во Свято-Миколаївської парафії, 1977. 174 с.

8. Карташев А. Вселенские соборы. Москва: Республика, 1994. 542 с.

9. К Катрій Ю. Пізнай свій обряд. Ч. 1. Ню-Йорк, Рим: Видавництво Отців Василіан, 1982. 493 с.

10. Кондаков Н. Иконография Господа Бога и Спаса Нашего Иисуса Христа. Лицевой иконописный подлинник. СПб., 1905 [Репринт] Москва: Паломникъ, 2001. 242 с.

11. Кондаковъ Н. П. Иконографрія Богоматери : в 2 т. Петроградъ: Изданіе Отдьленія Русскаго языка и Словесности Императорской Академіи Наукъ, 1914. Т. І. 387 с.; 1915. Т. II. 452 с.

12. Кондаковъ Н. Иконографрія Богоматери. Связи греческой и русской иконописи съ итальянскою живописью ранняго Возрожденія. С. Петербургъ: Т-во Р. Голике и А. Вильборгъ, 1910. 216 с.

13. Креховецький Я. Богослов'я та духовність ікони. Львів: Свічадо, 2000. 152 с. $275-329$.

14. Лазарев В. Этюды по иконографии Богоматери. Византийская живопись. Москва: Искусство, 1971. С.

15. Музичка І. Українське священне мистецтво і богословія. Богословія. Рим, 1993. Ч. 57. С. 146-150.

16. Остроґорський Ґ. Історія Візантії [пер. з нім. Анатолій Онишко] Львів: Літопис, 2002. 608 с.

17. Раушенбах Б. Пространственные построения в древнерусской живописи. Москва: Наука, 1975. 184 с.

18. Степовик В. Візантологія. Івано-Франківськ, 2002. С. 223-238. Видання 2-ге, доповнене, ілюстроване. 
Львів. Жовква, 2013.

19. Степовик Д. Іконологія й іконографрія. Івано-Франківськ: Нова Зоря, 2004. 320 с.

20. Степовик Д. Історія української ікони X - XX століть. Київ: Либідь, 1996. 440 с.

21. Степовик Д. Мистецтво ікони: Рим, Візантія, Україна. Київ: Наук. думка, 2007. 467 с.

22. Туркало Я. Нарис історії Вселенських соборів: 325-787. Брюссель, 1974. С. 259.

23. Український середньовічний живопис: альбом. Київ, 1976, таблиці 1-15.

24. Успенский Л., Успенская Л. О материалах в церковном искусстве. Журнал Московской патриархии.

Москва, 1988. № 11. С. 20-21.

25. Фаррар Ф. Жизнь Иисуса Христа. Новый перевод А. Лопухина с 30-го английского издания. СПб., 1893 (перевидання: Москва, 1991. С. 412-413).

26. Філософрський енциклопедичний словник. В. Шинкарук (голова редколегії) та ін.; Л. Озадовська, Н. Поліщук (наукові редактори) ; І. Покаржевська (художнє оформлення). Київ: Абрис, 2002. 742 с.

27. Флоренский А. Иконостас. Москва, 1995.

28. Флоровский Г. Восточные отцы V-VIII веков. Париж, 1933 (перевидання: Москва, 1992. С. 249).

29. Ouspensky L., Lossky V. ; The Meaning of Icons [trans. G. E. H. Palmer and E. Kadloubovsky]. New York: St. Vladimir's Seminary Press, 1982. $221 \mathrm{p}$.

30. Ouspensky L. Theology of the Icon. Vol. 1-2. New York: St. Vladimir's Seminary Press, 1992. 528 p.

31. St. John of Damascus. On the Divine Images: Three Apologies Against Those, Who Attack the Divine Images [David Anderson, Translator; English and Ancient Greek Edition]. New York: St. Vladimir's Seminary Press, 1997. $106 \mathrm{p}$.

32. Rice, D. Talbot. Byzantine Painting: the Last Phase. New York: Dial Press, 1968. 223 p.

33. The Glory of Byzantium. Art and Culture of the Middle Era. A.D. 843-1261. New York: The Metropolitan Museum, 1997; Byzantium. Faith and Power. 1261-1557. New York: The Metropolitan Museum, 2004.

34. Theodore The Studite. On the holy icons. [Catharine P. Roth, Translator]. New York: St. Vladimir's Seminary Press, $1981.115 \mathrm{p}$.

35. Tradigo A. Ikonen. Meisterwerke der Ostkirche. Bildlexikon der Kunst. Berlin: Parthas Verlag, 2005. 383 p.

\section{References}

1. Bychkov, V. (1977). Byzantine aesthetics. Theoretical problems. Moscow: Art [in Russian]

2. Bychkov, V. (1991). The Short History of Byzantine Aesthetics. Kiev: The Path to Truth [in Russian].

3. Bychkov, V. (1984). Aesthetics of Aurelius Augustine. Moscow: Art [in Russian].

4. Haluiko, R. (2012). Sophiological aspect of the dogma of icon veneration presented of Sergei Bulgakov. Visnyk of Lviv University. Series philosophical sciences. Vol. 15, pp. 227-234 [in Ukrainian].

5. Dionisiy Furnoagrafiot. (1868). Herminia, or Instructions in the pictorial art. [Compiled in 1701-1755]. Proceedings of the Kiev Theological Academy. Kiev. Vol. 2, p. 161 (Reproduction: Moscow, 1993) [in Russian].

6. Dubinskyi, B. (2000). The Shroud of Turin - a testimony of faith and the scientific mystery of the modern times. Purpose. Lviv, April, 4 (137) [in Ukrainian]. and English].

7. The iconography of St. Nicholas Church (1977). Toronto: Published by the parish of St. Nicholas [Ukrainian

8. Kartashev, A. (1994). Ecumenical Councils. Moscow: Republic [in Russian].

9. Katrii, Yu. (1982). Know your rite. Part 1. New York, Rome: Published by of the Basilian Fathers [in Ukrain-

ian].

10. Kondakov N. (2001). The iconography of the Lord God and our Savior Jesus Christ. St. Petersburg, 1905 [Reprint] Moscow: Pilgrim [in Russian].

11. Kondakov N. (1914). The iconography of the Mother of God: in 2 volumes. Petrograd: Edition of the Department of the Russian Language and Literature of the Imperial Academy of Sciences, T.I.; Kondakov N. (1915). The iconography of the Mother of God: in 2 volumes. Petrograd: Edition of the Department of the Russian Language and Literature of the Imperial Academy of Sciences, T.II. [in Russian].

12. Kondakov N. (1910). The iconography of the Virgin. Links of Greek and Russian iconography with Italian painting of the early Renaissance. St. Petersburg: A company R. Golike and A. Vilborg [in Russian].

13. Krekhovetskyi Ya. (2000). Theology and spirituality of icons. Lviv [in Ukrainian]. Russian]

14. Lazarev V. (1971). Etudes on the iconography of the Mother of God. Byzantine painting. Moscow: Art [in

15. Muzychka I. (1993). Ukrainian Sacral Arts and Theology. Theology Rome, Vol. 57, pp. 146-150 [in Ukrainian].

16. Ostrogorskyi G. (2002). History of Byzantium. Lviv: Chronicle [in Ukrainian].

17. Raushenbakh B. (1975). Spatial constructions in ancient Russian painting. Moscow: Science [in Russian].

18. Stepovyk V. (2013). Byzantology. Ivano-Frankivsk, 2002. pp. 223-238. Edition 2-th, supplemented, illustrated. Lviv. Zhovkva, 2013 [in Ukrainian].

19. Stepovyk D. (2004). Iconology and iconography. Ivano-Frankivsk: New Star [in Ukrainian].

20. Stepovyk D. (1996). History of Ukrainian icon X - XX centuries. Kyiv: Lybid. Kiev: Swan [in Ukrainian].

21. Stepovyk D. (2007). The Art of Icons: Rome, Byzantium, Ukraine. Kiev: Scientific thought [in Ukrainian].

Ukrainian]

22. Turkalo Ya. (1974). An Essay on the History of Ecumenical Councils: 325-787. Bryussel, p. 259 [in

23. Ukrainian medieval painting: album (1976). Kyiv, 1976, tables 1-15. [in Ukrainian].

24. Uspenskiy L., Uspenskaya L. (1988). About materials in church art. Journal of the Moscow Patriarchate. Moscow, Vol. 11, pp. 20-21 [in Russian].

25. Farrar F. (1893). The life of Jesus Christ. [New translation by A. Lopukhin from the 30th English edition]. St. Petersburg (reprint: Moscow, 1991, p. 412-413) [in Russian].

26. Philosophical Dictionary (2002). V. Shinkaruk (head of the editorial branch) and in; L. Ozadovska, N. 
Polishchuk (science editors); I. Pokarzhevska (artistic design). Kyiv: Abris [in Ukrainian].

27. Florenskiy A. (1995). Iconostasis. Moscow [in Russian].

28. Florovskiy G. (1933). Eastern fathers V - VIII centuries. Paris, (reprint: Moscow, 1992. p. 249) [in Russian].

29. Ouspensky L., Lossky V. (1982). The Meaning of Icons [trans. G. E. H. Palmer and E. Kadloubovsky]. New

York: St. Vladimir's Seminary Press [in English].

30. Ouspensky L. (1992). Theology of the Icon. Vol. 1-2. New York: St. Vladimir's Seminary Press [in English].

31. St. John of Damascus. (1997). On the Divine Images: Three Apologies Against Those, Who Attack the Divine Images [David Anderson, Translator; English and Ancient Greek Edition]. New York: St. Vladimir's Seminary Press [in English].

32. Rice, D. Talbot. (1968). Byzantine Painting: the Last Phase. New York: Dial Press [in English].

33. The Glory of Byzantium. Art and Culture of the Middle Era. A.D. 843-1261. (1997). New York: The Metropolitan Museum; Byzantium. Faith and Power. 1261-1557. (2004). New York: The Metropolitan Museum [in English].

34. Theodore The Studite. (1981). On the holy icons. [Catharine P. Roth, Translator]. New York: St. Vladimir's Seminary Press [in English].

35. Tradigo A. (2005). Icons. Masterpieces of the Eastern Church. Picture dictionary of art. Berlin [in German].

Стаття надійшла до редакції 23.10.2019 p. Прийнято до публікації 21.11.2019 p.

UDC 159.928.23:78.07

Kapliyenko-Iliuk Yuliya

Ph.D. in Arts, associate professor, doctoral student of the Odessa National

A. V. Nezhdanova Academy of Music

ORCID 0000-0002-6114-9680

yuliyakaplienko@gmail.com

\section{PSYCHOLOGICAL PRECONDITIONS OF MUSICAL CREATIVITY}

The purpose of the article is to analyze the psychological foundations of creative thinking as a prerequisite for musical creativity. The methodology is determined by the works in the field of psychology, which focus on the psychology of creativity, the problems of musical talent and creative thinking, encyclopedic resources, which reveal the essence of the notion of creativity, and musicology studies devoted to the issues of the creative process and musical activity. Scientific novelty consists of scientific comprehension of preconditions of musical creativity; in systematizing the psychological foundations of the creative process; in finding out the principles of creative thinking. Conclusions. Musical creativity is a complex process of artistic and creative thinking, which involves the creation of new spiritually valuable works. The psychological preconditions of musical creativity, such as talent, skill, intuition, creativity, and improvisation, are connected, first of all, with the psychic and mental development of the individual. However, the role of learning, acquiring skills and experience, the formation of imagination and accumulation of impressions is of great importance, because the process of creativity is associated with mental operations on the material primarily through conscious mechanisms. In the musical creativity there is an active and continuous correlation between the conscious and the unconscious. These two types of thinking complement each other, alternating depending on the tasks set before the composer. Creative tasks are realized with the help of creative-psychological settings, among which, the important role of emotions, intuition, reason, logic, rational principle, intelligence, and fantasy is evident.

Key words: the psychology of creativity, creative abilities, creative personality, creative thinking, talent, improvisation, creativity.

Каплієнко-Ілюк Юлія Володимирівна, кандидат мистецтвознавства, доцент, докторант Одеської національної музичної академії ім. А. В. Нежданової

Психологічні передумови музичної творчості

Мета статті - проаналізувати психологічні основи творчого мислення як передумови музичної творчості. Методологія визначається працями психологічного спрямування, де приділяється увага психології творчості, проблемам музичного таланту та творчого мислення, енциклопедичними джерелами, у яких розкривається сутність поняття творчості, музикознавчими дослідженнями, присвяченими питанням творчого процесу та музичної діяльності. Наукова новизна полягає у науковому осмисленні передумов музичної творчості; у систематизації психологічних основ творчого процесу; у з'ясуванні засад творчого мислення. Висновки. Музична творчість - це складний процес художньо-творчого мислення, що передбачає створення нових духовно цінних творів. Психологічні передумови музичної творчості, такі як талант, майстерність, інтуїція, креативність, імпровізація, пов'язані, перш за все, з психічно-розумовим розвитком суб'єкта. Однак, важлива роль навчання, набуття навичок і досвіду, формування уяви та накопичення вражень, адже процес творчості пов'язаний з розумовими операціями над матеріалом за допомогою, насамперед, свідомих механізмів. В музичній творчості безперервно відбувається активна та безперервна кореляція між свідомим та несвідомим. Ці два типи мислення взаємодоповнюють свої дії, чергуючись у залежності від поставлених завдань перед композитором. Творчі завдання реалізуються за допомогою творчо-психологічних установок, серед яких, важлива роль емоцій, інтуїції, розуму, логіки, раціонального начала, інтелекту, франтазії.

(c) Kapliyenko-Iliuk Yu., 2020 